\title{
Organizational climate, organizational commitment, job satisfaction, and employee performance
}

\author{
IRWAN SUGIARTO
}

Sekolah Tinggi Hukum Bandung, Indonesia

\begin{tabular}{ll}
\hline Abstract & The purpose of this study was to examine the relationship between organizational climate, \\
& organizational commitment, job satisfaction, and employee performance. Particularly, we \\
& examine the effect of organizational climate and organizational commitment on job \\
& satisfaction. Furthermore, we also test the effect of job satisfaction on employee \\
& performance. Results of path analysis on 90 respondents show sopports for all \\
& hypotheses. Partially, organizational climate and organizational commitment have positive \\
& effect on job satisfaction. Simultaneously, organizational climate and organizational \\
& commitment positively affect job satisfaction. In addition, job satisfaction has positive \\
& effect on employee performance.
\end{tabular}

\section{INTRODUCTION}

Employee performance is the key factor of organizational success (Alefari, Barahona, \& Salonitis, 2018; Osman, Shariff, \& Lajin, 2016) and organizational performance (Sugiarto, 2013). According to Rivai, Fawzi, Sagala, \& Murni (2008) performance relates to compensation and job satisfaction. Employees who are satisfied with their job will have positive feelings. While employees who are not satisfied with their job will have negative feelings (Robbins \& Judge, 2008). This notion was supported by some empirical evidence (Siengthai \& Pila-Ngarm, 2016; Adigun, Oyekunle, \& Onifade, 2017; Gul, Usman, Liu, Rehman, \& Jebran, 2018).

In relation to job satisfaction, former researchers used organizational climate variables as a dimension that can affect employee job satisfaction. Schneider \&Reichers (1983) on (Belias, Koustelios, Vairaktarakis, \& Sdrolias, 2015a) found the correlation between organizational climate and job satisfaction for employees in acertain job position.The results of Rahimic (2013; Khan, Ramzan, \& Butt (2013; Tsai (2014)showed that organizational climate significantly affected job satisfaction.

Another result by Ardakani, Ansari, \& Ardakani (2012a) revealed that organizational climate has a correlation with organizational commitment. Commitment is described as an attitude of having a strong desire to remain in a certain organization, strive according to the organization wishes, and belief in the acceptance of organizational values and goals (Luthans, 2006).

According to the description above, this study aims to the relationship between organizational climate, organizational commitment, job satisfaction, and employee performance. Particularly, we examine the effect of organizational climate and organizational commitment on job satisfaction. Furthermore, we also test the effect of job satisfaction on employee performance.

\section{HYPOTHESES DEVELOPMENT}

\section{Effect of organizational climate on job satisfaction}

The organizational climate is quite interesting and important, because of its benefits for people, community, and also industry. For individuals, the effective organizational climate will improve motivation. For industries, the manager will be able to determine how employees generally perceive organizational management. Furthermore, the community will certainly relish the maximum results from the industry as well as the maximum increase in value from the industry, and also rising values in the context of work. 
The study about organizational climate can be traced to 1939 through the work of Kurt Lewin and continues to be the focus of empirical research. 'organizational climate' as a word created by Cornell (1956) and stated it as "a subtle blend of interpretations or perceptions by people in the organization of work orroles in relationships with others and interpretations of the roles of others in the organization" (Datta \& Singh, 2018). Organizational climate represents the condition of organizational culture. The most common management problem that faced by organizations today is to find a flexible and creative work environment that promotes job satisfaction and innovation (Permarupan, Saufi, Kasim, \& Balakrishnan, 2013). Organizational climate is a subjective perception of studies regarding the physical, objective environment, organizational application and condition(Akbaba \& Altındağ, 2016). Organizational climate is reflected in the organization's goal of developing staff by providing good working environments and conditions and also helping and supporting employees to achieve job satisfaction (Bahrami, Barati, Ghoroghchian, Montazeralfaraj, \& Ranjbar Ezzatabadi, 2016).

In relation to job satisfaction, some former researchers used organizational climate variables as dimensions that can affect employee job satisfaction. Kirilo et al. (2018) said that the organizational climate has a direct impact on the quality of work life, which is related to satisfaction and emotion. Schneider and Reichers (1983) in Belias, Koustelios, Vairaktarakis, \& Sdrolias (2015) find a correlation between organizational climate and job satisfaction for employees in certain job positions. The results of the study Rahimic (2013; Khan, Ramzan, \& Butt (2013; Tsai (2014) showed that organizational climate has a significant effect on job satisfaction. According to Kolb, Rubin, \& Mclntyre (1984), there are seven aspects that can identify the organizational climate in a company, those are conformity, responsibility, performance standards, rewards, organizational clarity, warmth and support, and leadership.

H1: Organizational climate positively affects job satisfaction.

\section{Effect of organizational commitment on job satisfaction}

Commitment is described as an attitude that has a strong desire to remain in a certain organization, strives hard according to the wishes of the organization, and confidence in the acceptance of values and goals of the organization (Luthans, 2006b). According to (Robbins, 2006), employee commitment to the organization is up to the level where an employee sided with a particular organization and its objectives and intends to maintain membership in a certain organization. Employee's work commitment determines the success or failure of the goals to be achieved by an organization or company. This means that if every member of the organization has a high commitment, it is likely that success can be achieved. The success of an organization will have a good impact on the survival of the organization or company and its employees.

Organizational commitment shows employee commitment (Yao, Qiu, \& Wei, 2019) and employee affiliation to an organization (Ahmad, lqbal, Javed, \& Hamad, 2014). Organizational commitment is defined as the emotional relationship between employees and organizations which consists of affective commitment, normative commitment, and ongoing commitment (Allen \& Meyer, 1990; Labrague et al., 2018).

Some former researchers stated that organizational commitment has a positive influence on job satisfaction. Results of the research Ahmad et al. (2014); Slattery \& Rajan Selvarajan (2005), showed that organizational commitment has a positive and significant effect on employee job satisfaction. Aydogdu \& Asikgil (2011) conducted a study of 100 employees from the production sector and 82 employees from the service provider sector. The results of his research showed the fact that three organizational commitments have a positive and significant relationship with job satisfaction.

H2: Organizational commitment positively affects job satisfaction.

\section{Effect of organizational climate and organizational commitment on job satisfaction}

A conducive organizational climate is important to be made because it is one's perception of what is given by the organization and is used as the basis for determining the 
behavior of the next member. The organizational climate is determined by how well members are directed, built, and respected by the organization. Steers (1984) said that the concept of organizational climate itself is the traits or characteristics that are felt in the work environment and arise because of the activities of the organization and can affect the behavior of the people in it.

A conducive climate will lead to job satisfaction and high commitment to each individual working within the organization.Brown \& Leigh (1996)said that the organizational climate is very important because organizations that can create an environment where employees feel friendly can achieve full potential in seeing the key to competitive advantage. Therefore the organizational climate can be seen as a key variable of organizational success.

The organizational climate is often associated with the level of organizational commitment. Mowday, Steers, \& Porter (1979) stated that organizational commitment refers to identifying organizational goals, willingness to mobilize all resources for the benefit of the organization, and interest in remaining part of the organization. According to Shore \& Tetrick (1991), employee commitment to the organization has a significant relationship with workers perceptions of company commitment to workers (perceived organizational support) as a reciprocal of organizational perceptions of their attitudes and behavior.

The former researchers in carrying out their research used many organizational climate variables and organizational commitment as dimensions that could affect employee job satisfaction. The results of (Ardakani, Ansari,

\& Ardakani, 2012b) revealed that the organizational climate has a significant influence on organizational commitment. Bhaesajsanguan (2010) examined the relationship between organizational climate, job satisfaction and organizational commitment in the Thai Telecommunications Industry, the results of the study proved that the organizational climate has a positive relationship with job satisfaction. The results of his research also revealed that the organizational climate has a positive relationship with organizational commitment and has a positive effect on job satisfaction.

Job satisfaction itself actually has meaning for a worker, there are two words, which are satisfaction and work. Satisfaction is something that is experienced by someone, where what is expected has been fulfilled or even received more than expected, while work is a person's effort to achieve the goal by obtaining income or compensation from his contribution to his work.Robbins (2006), said that job satisfaction is a general attitude towards someone's work that shows the difference between the number of awards received by workers and the amount they believe they should receive.

The behavior shown by leaders, managers, and group members has an impact on the attitudes and perceptions of employees about their work and organization (Church, 1995). Often, individuals in a workgroup differ in their perceptions of their working environment (Hershberger, Lichtenstein, \& Knox, 1994). This indicates the absence of the same perception about the organizational climate. As a consequence, individuals feel different perceptions in the organizational climate and Table 1.

Partial Effect of Variables (X1) and (X2) on (Y)

Coefficients $^{\mathrm{a}}$

\begin{tabular}{lrrrrrr}
\hline \multirow{2}{*}{ Model } & \multicolumn{2}{c}{ Unstandardized Coefficients } & Standardized Coefficients & & \\
\cline { 2 - 6 } & B & Std. Error & Beta & & Sig. \\
\hline 1 & (Constant) & 10,340 & 3,061 & 3,378 &, 001 \\
X1 &, 418 &, 055 &, 467 & 7,664 &, 000 \\
X2 &, 542 &, 061 &, 540 & 8,860 &, 000 \\
\hline \multicolumn{2}{l}{ a. Dependent Variable:Y $Y$} & & & &
\end{tabular}

Table 2.

The simultaneous effect of organizational climate and organizational commitment on job satisfaction

Model Summary

\begin{tabular}{lrrrr}
\hline Model & $\mathrm{R}$ & $\mathrm{R}$ Square & Adjusted R Square & Std. Error of the Estimate \\
\hline 1 &, $867^{\mathrm{a}}$ &, 752 &, 747 & 4,34663 \\
\hline a. & Predictors: (Constant), $\mathrm{X} 2, \mathrm{X} 1$ & & &
\end{tabular}




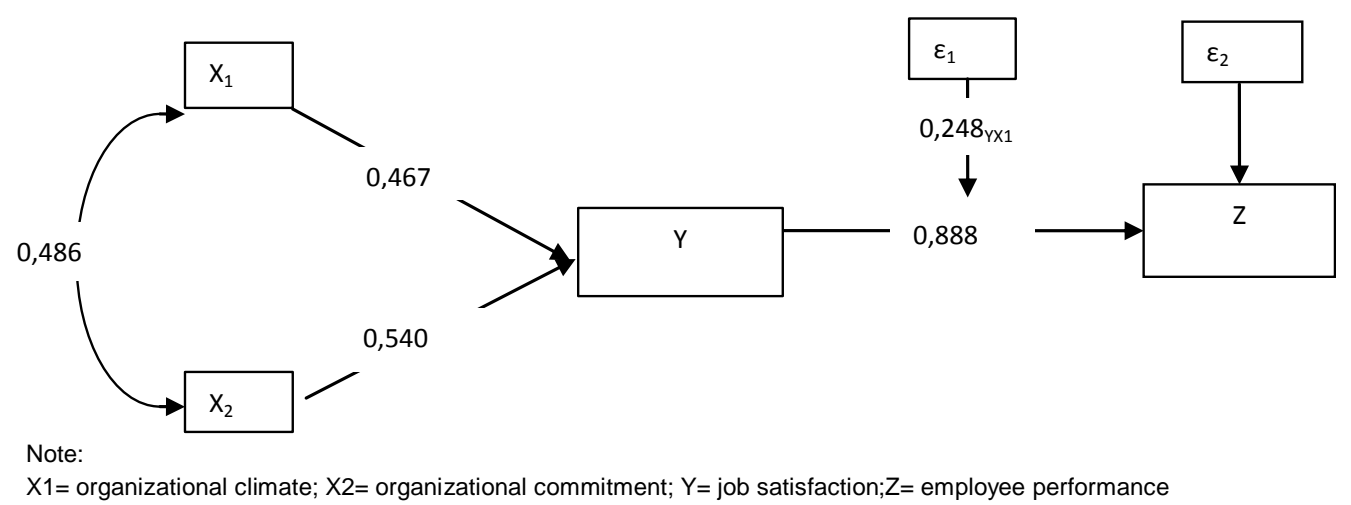

Figure 1.

Path analysis result

also differences in job satisfaction. Although perceptions of job satisfaction and organizational climate are related and provide reciprocal influence with one another, job satisfaction is a concept that is different from the organizational climate. According to Nath Gangai \& Agrawal (2015)job satisfaction or dissatisfaction leads to a number of consequences. Satisfaction leads to more productivity, high quality and intention to remain in the organization, while job dissatisfaction is found to increase absence, turnover, high stress, and complaints.

Rogg, Schmidt, Shull, \& Schmitt (2001) measured work climate and customer satisfaction with a sample of managers in small companies who became the object of research and employees as the customers. The results of his research explain that the work climate with job satisfaction has a very strong relationship when compared to the relationship between the organizational structure with job satisfaction, or between work results with job satisfaction, and between processes in organizations with job satisfaction. The results of the research of Allahyari \& Eftekhari (2013 and Aydogdu \& Asikgil (2011) showed that there is a direct and significant relationship between job satisfaction and all aspects of organizational commitment.

The organizational climate and commitment are expected to increase employee job satisfaction. The relationship described is a causal relationship where the organizational climate has a positive influence on work satisfaction, organizational commitment has a positive influence on job satisfaction, and the organizational climate and commitment together have an influence on job satisfaction.
Based on the mentioned above, the third hypothesis in this study is as follows:

H3:Organizational climate and organizational commitment positively affects job satisfaction.

\section{Effect of job satisfaction on performance}

Performance is basically what employees do and don't. How much the achievement of employee performance will contribute to organizational performance (Mathis \& Jackson, 2006) and will have an influence on organizational performance (Sugiarto, 2013b). According to Gomes aspects of performance criteria consist of Quantity of work, Quality of work, Job knowledge, Creativeness, Cooperation, and Dependability(Gomes, 2010).

Performance does not stand alone but relates to compensation and job satisfaction (Rivai et al., 2008). Employees who are satisfied with their work will have positive feelings. While employees who are not satisfied with their work will have negative feelings (Robbins \& Judge, 2008). According to Luthans (2006), there are five work dimensions that have been identified to represent the most important job characteristics where employees have an affective response, those are 1. Payments, such as salaries and wages, 2 . Work itself, 3. Colleagues, 4.Promotion job, 5. Supervision (supervise).

Empirical evidence stated that job satisfaction is one of the factors that can improve performance (Siengthai \& PilaNgarm, 2016; Adigun, Oyekunle, \& Onifade, 2017; Gul, Usman, Liu, Rehman, \& Jebran, 2018), the results of their research showed that job satisfaction has a positive and significant 
Table 3.

Partial effect of job satisfaction on employee performance

Coefficients $^{a}$

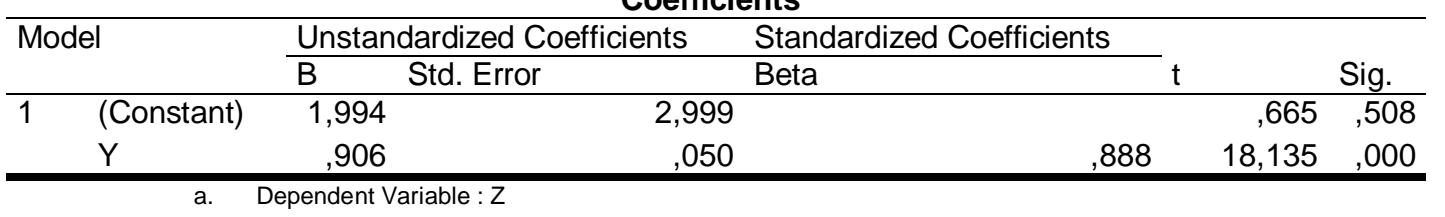

Table 4.

Effect of Organizational Climate (X1) on Job Satisfaction (Y)

\begin{tabular}{llll}
\hline Variable & Path Analysis Interpretation & Calculation Process & The amount of influence \\
\hline $\mathrm{X}_{1}$ & Direct effect on $\mathrm{Y}$ & $0,467^{2}$ & 0,218 \\
& Indirect effect on $\mathrm{Y}$ through $\mathrm{X}_{2}$ & $0,467 \times 0,486 \times 0,540$ & 0,123 \\
& Total & & $\mathbf{0 , 3 4 1}$ \\
\hline
\end{tabular}

effect on performance. The effect is positive because employees who are satisfied with their work will be happy to do the work and strive to continually improve their abilities and skills so that more professionals carry out tasks within the organization will improve employee performance and overall organizational performance.

Based on the mentioned above, the fourth hypothesis in this study is as follows:

\section{H4:Job satisfaction positively affects performance.}

\section{METHODS}

This research was conducted at the head office of PT XYZ (Persero). The population in this research were all employees of $P T X Y Z$ (Persero) Operational Unit, with 868 employees. Determination of the number of the samples using the slovin formula (Umar, 2004 ), with an error rate of $10 \%$ and the results of calculations using the formula obtained the number of the samples of 90 employees of PT XYZ (Persero) Operational Unit that was made as respondents. The research method used a quantitative method with a descriptive analysis approach. Data collection techniques were conducted through questionnaire and study literature. Before the data was used, the validity test, reliability test, and distribution normality test were conducted to determine the accuracy, reliability, and normality of the data. The data analysis techniques used in this study were descriptive analysis and path analysis. Path analysis was used to show the correlation that describes how much the influence of a certain variable both direct and indirect influences on the other variables.

The results of the validity test show that all variable were valid with the value 0.927 for organizational climate, 0.896 for organizational commitment, 0.890 for job satisfaction, and 0.894 for employee performance. Thus, the instrument that used in this study can be declared as a reliable and truly measuring instrument and have a high level of stability.

\section{RESULTS AND DISCUSSION}

\section{Path analysis}

Analysis of correlation and regression is a base of the path coefficient calculation (Riduwan \& Kuncoro, 2008). The test results of partial effect of organizational climate and organizational commitment on job satisfaction is shown in table 1.

Then, simultaneous effect of independent variables on the dependent variables were known as the multiple regression coefficient and determination coefficient. Determination coefficient (square multiple correlation) is the coefficient used to determine the magnitude of the contribution of independent variables on the changes of dependent variable. The results of path analysis from the simultaneous effect of organizational climate and organizational commitment on job satisfaction is shown in table 2. 
Table 5.

Effect of organizational commitment on job satisfaction

\begin{tabular}{llll}
\hline Variable & Path Analysis Interpretation & Calculation Process & The amount of influence \\
\hline $\mathrm{X}_{2}$ & Direct effect on $\mathrm{Y}$ & $0,540^{2}$ & 0,292 \\
& Indirect effect on $\mathrm{Y}$ through $\mathrm{X}_{1}$ & $0,540 \times 0,486 \times 0,467$ & 0,123 \\
& & $\mathbf{0 , 4 1 5}$ \\
\hline Total & &
\end{tabular}

Table 6.

The simultaneous effect of organizational climate and organizational commitment on job satisfaction

\begin{tabular}{rrrrr}
\multicolumn{5}{c}{ Model Summary } \\
\hline \multicolumn{1}{c}{ Model } & $\mathrm{R}$ & $\mathrm{R}$ Square & Adjusted R Square & Std. Error of the Estimate \\
\hline 1 &, $867^{\mathrm{a}}$ &, 752 &, 747 & 4,34663 \\
\hline a. & Predictors: (Constant), X2, X1 & & &
\end{tabular}

The results of the partial effect of job satisfaction on employee performance can be seen on table 3 . Furthermore, we can see the results of the path analysis in figure 1. As shown in figure 1 , the effect of organizational climate on job satisfaction has path coefficient 0.467 and the effect of organizational commitment on job satisfaction has path coefficient 0.540 . In addition, the effect of job satisfaction on employee performance has path coefficient 0.888 .

\section{The effect of organizational climate on job satisfaction}

Based on the results of the path analysis calculation above, it can be seen the direct effect and indirect regarding the influence of organizational climate on job satisfaction as shown in table 4.

Based on the table 4, it can be seen that organizational climate has a direct effect on job satisfaction with the value of 0.218 or $21.8 \%$, while the indirect effect through variable of organizational commitment has a value of 0.123 or $12.3 \%$, so the effect of total variables organizational climate on job satisfaction has a value of 0.341 or $34.1 \%$.

It provides empirical evidence that there is an effect of organizational climate on employee job satisfaction. With the proof of the hypothesis proposed in this study, the results of this study support the results of research that conducted by Rahimic (2013), Khan et al., (2013), and (Tsai, 2014) which overall concluded that organizational climate has a significant effect on job satisfaction.

\section{Effect of organizational commitment on job satisfaction}

Based on the calculation of path analysis above, it can be seen that the direct and indirect effect regarding to the effect of organizational commitment on job satisfaction as shown in table 5 . Based on the table 5, it can be seen that organizational commitment has a direct effect on job satisfaction with the value 0.292 or $29.2 \%$, while the indirect effect through the organizational climatehas the value 0.123 or $12.3 \%$, so that the total effect of organizational commitment variable on job satisfaction has the value 0.415 or $41.5 \%$

Thus, it can be stated that organizational commitment can contribute to improving job satisfaction. It provides empirical evidence that there is an effect of organizational commitment on employee job satisfaction. With the proof of the hypothesis proposed in this study, organizational commitment influences job satisfaction, this study proves supports for the results of previous research, which is conducted by Slattery \& Selvarajan (2005), Aydogdu \& Asikgil (2011) which stated that organizational commitment has a significant influence on job satisfaction.

\section{Effect of organizational climate and organizational commitment on job satisfaction}

The results of path analysis from the simultaneous effect of organizational climate variable and organizational commitment on job satisfaction obtained the contribution of these two variables at 0.752 or $75.2 \%$ while the remainder of $1-\mathrm{R}=1-0.752=0.248$ or $24.8 \%$ is the contribution of other variables 
Table 7.

Simultaneous effect of job satisfaction on employee performance

Model Summary

\begin{tabular}{|c|c|c|c|c|}
\hline Model & $\mathrm{R}$ & R Square & Adjusted R Square & Std. Error of the Estimate \\
\hline 1 &, $888^{\mathrm{a}}$ & ,789 & ,787 & 4,06965 \\
\hline
\end{tabular}

that are not examined in this study. The results are shown in table 6 .

The simultaneous effect of organizational climate and organizational commitment on job satisfaction can be seen in $\mathrm{R}$ square with the value of 0.752 or $75.2 \%$, while the rest of 0.248 or $24.8 \%$ is the contribution of other variables that are not examined in this study. This showed that organizational climate and organizational commitment together and synergize well have a significant effect on the variable job satisfaction, where the organizational commitment has the most dominant effect with the value 0.415 or $41.5 \%$ compared to the organizational climate variable with the value of 0.341 or $34.1 \%$.

The result of this study supports previous research that conducted by Bhaesajsanguan (2010), and Ardakani et al., (2012) which stated that job satisfaction will be carried out and fulfilled if several variables that influence it to support it once. These variables are referred to organizational climate and organizational commitment.

\section{Effect of job satisfaction on employee performance}

Based on the statistical calculation of path coefficient (table 11), it was found that job satisfaction have positive effect on employee performance. The effect of job satisfaction on employee performance is shown by the results of statistical testing, where R Square is 0.789 or $78.9 \%$, $t$ means that job satisfaction significantly affects employee performance of $78.9 \%$, in the strong category, while the rest of 0.211 or $21.1 \%$ is the contribution of other variables that are not examined in this study.

With the proof of the hypothesis proposed in this study, this study supports the results of previous research. Empirical evidence expressed by Siengthai \& Pila-Ngarm (2016); Adigun et al., (2017); Gul et al., (2018) stated that job satisfaction affects performance. The effect is positive because employees who are satisfied with their job will be happy to do their job and tries to continually improve their abilities and skills so that more professionals carry out tasks within the organization which ultimately lead to improving the performance in question and overall organizational performance.

\section{CONCLUSION}

Based on the result and data processing, this study can be concluded that all the proposed hypotheses are accepted. The study showed that Partially, organizational climate and organizational commitment have positive effect on job satisfaction. Simultaneously, organizational climate and organizational commitment positively affect job satisfaction. In addition, job satisfaction has positive effect on employee performance.

\section{REFERENCES}

Adigun, A. O., Oyekunle, I. A., \& Onifade, T. (2017). Influence Of Job Satisfaction On Employees' Performance In MTN Nigeria. Global Journal of Human Resource Management, 5(5), 54-60.

Ahmad, N., lqbal, N., Javed, K., \& Hamad, N. (2014). Impact of organizational commitment and employee performance on the employee satisfaction. International Journal of Learning, Teaching and Educational Research, 1(1), 84-92.

Akbaba, Ö., \& Altındağ, E. (2016). The Effects of Reengineering, Organizational Climate and Psychological Capital on the Firm Performance. Procedia - Social and Behavioral Sciences, 235, 320-331. https://doi.org/10.1016/j.sbspro.2016.11.03 8

Allahyari, M. S., \& Eftekhari, H. (2013). Relationship between job satisfaction and organizational commitment of agricultural extension experts of Guilan Province. Indian Journal of Fundamental and Applied Life Sciences, ISSN, 2231-6345.

Allen, N. J., \& Meyer, J. P. (1990). The measurement and antecedents of affective, continuance and normative commitment to the organization. Journal of Occupational Psychology, 63(1), 1-18.

Ardakani, S. R., Ansari, A., \& Ardakani, M. R. (2012a). Organizational Climate And Commitment. Researcher, 4(12), 3-5. 
Ardakani, S. R., Ansari, A., \& Ardakani, M. R. (2012b). Organizational Climate And Commitment. Researcher, 4(12).

Aydogdu, S., \& Asikgil, B. (2011). An empirical study of the relationship among job satisfaction, organizational commitment,and turnover intention. International Review of Management and Marketing, 1(3), 43-53.

Bahrami, M. A., Barati, O., Ghoroghchian, M., Montazer-alfaraj, R., \& Ranjbar Ezzatabadi, M. (2016). Role of Organizational Climate in Organizational Commitment: The Case of Teaching Hospitals. Osong Public Health and Research Perspectives, 7(2), 96-100. https://doi.org/10.1016/j.phrp.2015.11.009

Belias, D., Koustelios, A., Vairaktarakis, G., \& Sdrolias, L. (2015a). Organizational Culture and Job Satisfaction of Greek Banking Institutions. Procedia - Social and Behavioral Sciences, 175, 314-323. https://doi.org/10.1016/j.sbspro.2015.01.12 06

Belias, D., Koustelios, A., Vairaktarakis, G., \& Sdrolias, L. (2015b). Organizational Culture and Job Satisfaction of Greek Banking Institutions. Procedia - Social and Behavioral Sciences, 175, 314-323. https://doi.org/10.1016/j.sbspro.2015.01.12 06

Bhaesajsanguan, S. (2010). The Relationships among organizational climate, Job satisfaction and organizational commitment in the Thai telecommunication industry. E-Leader Singapore Journal, 10, $1-15$.

Brown, S. P., \& Leigh, T. W. (1996). A new look at the psychological climate and its relationship to job involvement, effort, and performance. Journal of Applied Psychology, 81(4), 358.

Church, A. H. (1995). Managerial behaviors and work group climate as predictors of employee outcomes. Human Resource Development Quarterly, 6(2), 173-205.

Datta, A., \& Singh, R. (2018). Determining the dimensions of organizational climate perceived by the hotel employees. Journal of Hospitality and Tourism Management, 36 , $40-48$. https://doi.org/10.1016/j.jhtm.2018.07.001

Gomes, F. C. (2010). Faustino Cardoso Gomes, Manajemen Sumber Daya Manusia. Yogyakarta: Penerbit Andi.

Gul, H., Usman, M., Liu, Y., Rehman, Z., \& Jebran, K. (2018). Does the effect of power distance moderate the relation between person environment fit and job satisfaction leading to job performance? Evidence from Afghanistan and Pakistan. Future Business Journal, 4(1), 68-83. https://doi.org/10.1016/j.fbj.2017.12.001

Hershberger, S. L., Lichtenstein, P., \& Knox, S. S. (1994). Genetic and environmental influences on perceptions of organizational climate. Journal of Applied Psychology, 79(1), 24.

Indonesia, P. K. A. I. (Persero). (2017). Melayani Kebutuhan Masyarakat Melalui Inovasi dan Perbaikan Berkelanjutan Menuju Era Modern Serving the Needs of Society through Innovation and Continuous Improvement towards a Modern Era. Annual Report.

Khan, A., Ramzan, M., \& Butt, M. S. (2013). Is job satisfaction of Islamic banks operational staff determined through organizational climate, occupational stress, age and gender. Journal of Business Studies Quarterly, 4(3), 13

Kirilo, C. Z., Abe, J. M., de Lima, L. A., Machi Lozano, L. C., Nogueira, M., de Oliveira, C. C., \& Nakamatsu, K. (2018). Organizational Climate Assessment Using the Paraconsistent Decision Method. Procedia Computer Science, 131, 608618.

https://doi.org/10.1016/j.procs.2018.04.303

Kolb, D. A., Rubin, I. M., \& Mclntyre, J. M. (1984). Organizational Psychology: An Experiential Approach to Organizational Behavior (6th ed.). Englewood Cliffs: N.J.: Prentice-Hall.

Labrague, L. J., McEnroe - Petitte, D. M., Tsaras, K., Cruz, J. P., Colet, P. C., \& Gloe, D. S. (2018). Organizational commitment and turnover intention among rural nurses in the Philippines: Implications for nursing management. International Journal of Nursing Sciences, 5(4), 403-408. https://doi.org/10.1016/j.ijnss.2018.09.001

Luthans, F. (2006a). Perilaku Organisasi. Yogyakarta: Penerbit Andi.

Luthans, F. (2006b). Perilaku Organisasi. Yogyakarta: Penerbit Andi.

Luthans, F. (2006c). Perilaku Organisasi. Yogyakarta: Penerbit Andi.

Mathis, R. L., \& Jackson, J. H. (2006). Manajemen Sumber Daya Manusia. Jakarta: Salemba Empat.

Mowday, R. T., Steers, R. M., \& Porter, L. W. (1979). The measurement of organizational commitment. Journal of Vocational Behavior, 14(2), 224-247.

Nath Gangai, K., \& Agrawal, R. (2015). Job satisfaction and organizational 
commitment: Is it important for employee performance. International Journal of Management and Business Research, 5(4), 269-278.

Osman, S., Shariff, S. H., \& Lajin, M. N. A. (2016). Does Innovation Contribute to Employee Performance? Procedia - Social and Behavioral Sciences, 219, 571-579. https://doi.org/10.1016/j.sbspro.2016.05.03 6

Permarupan, P. Y., Saufi, R. A., Kasim, R. S. R., \& Balakrishnan, B. K. P. D. (2013). The Impact of Organizational Climate on Employee's Work Passion and Organizational Commitment. Procedia Social and Behavioral Sciences, 107, 8895.

https://doi.org/10.1016/j.sbspro.2013.12.40 3

Rahimic, Z. (2013). Influence of Organizational Climate on Job Satisfaction in Bosnia and Herzegovina Companies. International Business $\quad$ 6(3). https://doi.org/10.5539/ibr.v6n3p129

Riduwan, \& Kuncoro, E. A. (2008). Cara Menggunakan dan Memakai Analisis Jalur (Path Analysis) (2nd ed.). Bandung: Alfabeta.

Rivai, V., Fawzi, A., Sagala, E. J., \& Murni, S. (2008). Performance Appraisal Sistem Yang Tepat Untuk Menilai Kinerja Karyawan dan Meningkatkan Daya Saing Perusahaan. Jakarta: Raja Grafindo Persada.

Robbins, S. P. (2006). Perilaku Organisasi (10th ed.). Jakarta: Indeks Kelompok Gramedia.

Robbins, S. P., \& Judge, T. A. (2008). Perilaku Organisasi. Jakarta: Salemba Empat.

Rogg, K. L., Schmidt, D. B., Shull, C., \& Schmitt, N. (2001). Human resource practices, organizational climate, and customer satisfaction. Journal of Management, 27(4), 431-449. https://doi.org/10.1177/014920630102700 403

Shore, L. M., \& Tetrick, L. E. (1991). A construct validity study of the survey of perceived organizational support. Journal of Applied Psychology, 76(5), 637.

Siengthai, S., \& Pila-Ngarm, P. (2016). The interaction effect of job redesign and job satisfaction on employee performance. Evidence-Based HRM: A Global Forum for Empirical Scholarship, 4(2), 162-180. https://doi.org/10.1108/EBHRM-01-20150001

Slattery, J. P., \& Rajan Selvarajan, T. T. (2005). Antecedents to Temporary Employee's Turnover Intention. Journal of Leadership
\& Organizational Studies, 12(1), 53-66. https://doi.org/10.1177/107179190501200 106

Steers, R. M. (1984). Efektifitas Organisasi: Kaidah Perilaku (Magdalena Jamin). Jakarta: Erlangga.

Sugiarto, I. (2013). Pengaruh Budaya Organisasi Dan Motivasi Kerja Terhadap Kepuasan Kerja Serta Implikasinya Terhadap Kinerja Karyawan. Banking \& Management Review, 2(1), 165-180. https://doi.org/10.24912/jm.v19i2.129

Sugiyono. (2004). Metode Penelitian Bisnis. Bandung: Alfabeta.

Tsai, C. (2014). The organizational climate and employees' job satisfaction in the Terminal Operation Context of Kaohsiung Port. The Asian Journal of Ship and Log, 30(3), 373392.

Umar, H. (2004). Riset Sumber Daya Manusia. Jakarta: Gramedia Pustaka Utama.

Yao, T., Qiu, Q., \& Wei, Y. (2019). Retaining hotel employees as internal customers: Effect of organizational commitment on attitudinal and behavioral loyalty of employees. International Journal of Hospitality Management, 76, 1-8. https://doi.org/10.1016/j.ijhm.2018.03.018 